\title{
Obalni ekosistemi na prehodu: Primerjalna analiza severnega Jadrana in Zaliva Chesapeake
}

\author{
Jadran Faganeli, ${ }^{\star}$ Alenka Malej* \\ Morska biološka postaja, Nacionalni inštitut za biologijo, Fornače 41, 6330 Piran, Slovenija \\ *Corresponding author: E-mail: jadran.faganeli@nib.si, Tel.: +38659232911 \\ alenka.malej@nib.si,Tel.: +38659232903
}

Received: 08-12-2020

\section{Izvleček}

Predstavljena je vsebina knjige v tisku pri založbi AGU-Wiley z naslovom »Obalni ekosistemi na prehodu: Primerjalna analiza severnega Jadrana in Zaliva Chesapeake« urednikov T. Maloneja, A. Malej in J. Faganelija. Knjiga prinaša primerjavo ekosistemov severnega Jadrana in Zaliva Chesapeake (vzhodna obala ZDA) in širi znanje o antropogenih vplivih na obalne ekosisteme, kjer je koncentrirano tako prebivalstvo kot izkoriščanje naravnih virov. Ponovni pregled obeh ekosistemov je omogočil, da smo ocenili spremembe v zadnjih 20 letih, še posebej lokalne vplive v okviru globalnih podnebnih sprememb ter uspešnost posegov za upravljanje in zmanjšanje antropogenih vplivov na obalne ekosisteme.

Ključne besede: obalno morje, severni Jadran, Chesapeake Bay, antropogeni vplivi

Knjiga $\mathrm{v}$ tisku pri založbi AGU-Wiley $\mathrm{z}$ naslovom »Obalni ekosistemi na prehodu: Primerjalna analiza severnega Jadrana in Zaliva Chesapeake « ${ }^{1}$ (ISBN 9781119543589) posodablja in razširja naše znanje o učinkih človekovih dejavnosti na obalne ekosisteme, kjer je koncentrirano tako prebivalstvo kot izkoriščanje naravnih virov (slika 1). Knjiga je posvečena 50-letnici delovanja Morske biološke postaje NIB v Piranu in podaja novo analizo obeh ekosistemov, ki so bili predstavljeni leta 1999 v objavljeni knjigi »Ekosistemi na prehodu kopno-morje: Od porečja do morja«. ${ }^{2}$ Ponovni pregled je omogočil, da smo ocenili spremembe $\mathrm{v}$ zadnjih 20 letih, učinke lokalnih vplivov v luči globalnih podnebnih sprememb in zlasti uspešnost posegov za upravljanje in zmanjšanje antropogenih vplivov na ekosisteme. Knjiga obsega 11 poglavij slovenskih, ameriških, italijanskih in hrvaških avtorjev (v oklepaju), ki vključujejo: uvodne besede o ogroženih obalnih ekosistemih (T. Malone, A. Malej, J. Faganeli), rečne pritoke (Q. Zhang, S. Cozzi, C. Palinkas, M. Giani), tokovanje in podnebne spremembe (W.V. Boicurt, M. Ličer, M. Li, M. Vodopivec, V. Malačič), fitoplankton (M.J. Brush, P. Mozetič, J. France', F. Bernardi Aubry, T. Djakovac, J. Faganeli, L. Harris, M. Niesen), zooplankton (J. Pierson, E. Camatti, R. Hood, T. Kogovšek, D. Lučić, V. Tirelli, A. Malej), vlogo mikrobov (V. Turk, S. Malkin, M. Celussi, T. Tinta, J. Cram, F. Malfatti, F. Chen), evtrofikacijo, pomanjkanje kisika in »kisanje« morja $(M$. Brush, $M$.

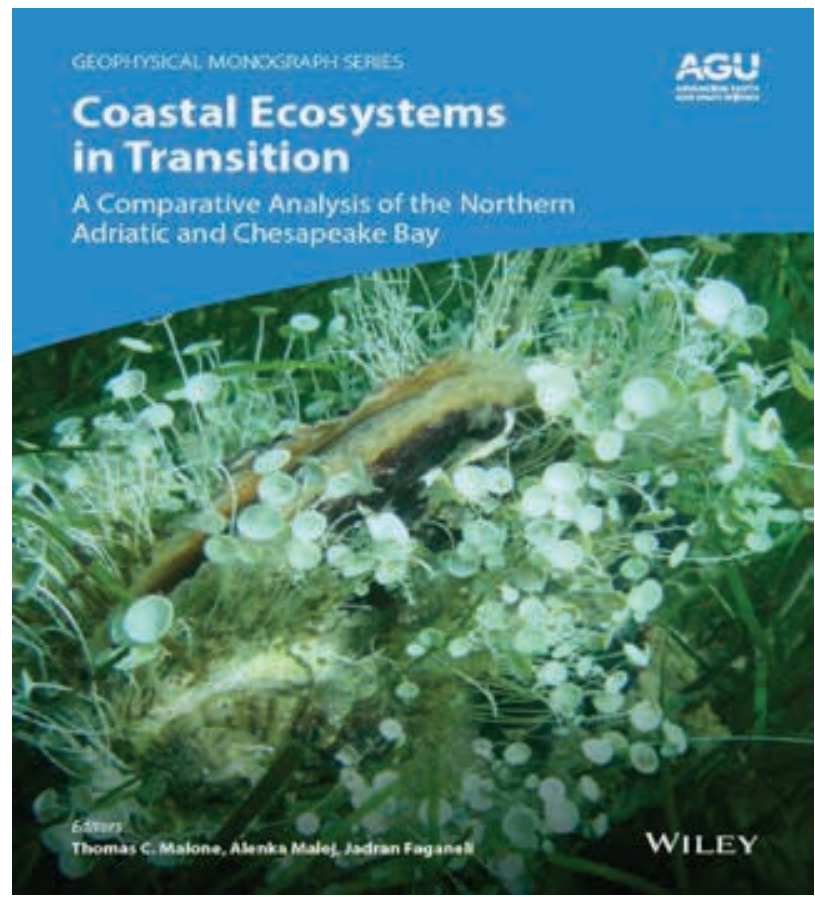

Slika 1: Naslovnica knjige

Giani, C. Totti, J. Testa, J. Faganeli, N. Ogrinc, M. Kemp, $\mathrm{S}$. Fonda Umani), sklopitev pelagiala in bentosa $\mathrm{z}$ vidika kroženja organskega ogljika $\left(\mathrm{C}_{\text {org. }}\right)$, dušika $(\mathrm{N})$, fosforja 
(P) in silicija (Si) (J.M. Testa, J. Faganeli, M. Giani, M.J. Brush, C. de Vittor, S. Covelli, W.R. Boynton, W.M. Kemp, $\mathrm{N}$. Kovač, R. Woodland), ključne habitate in tujerodne vrste (C. Palinkas, M. Mistri, L. Staver, L. Lipej, P. Kružić, J. Court Stevenson, M. Tamburri, C. Munari, M. Orlando Bonaca), ribištvo (V.S. Kenneddy, L. Bolognini, J. Dulčić, R.J. Woodland, M.J. Wilberg, L.A. Harris) in zaključke o upravljanju ekosistemov in prognozah v prihodnosti (A. Malej, J. Faganeli, T. Malone). Knjiga je lahko, glede na vsebino, učbenik o severnem Jadranu.

\section{Ključni ekološki dejavniki v severnem Jadranu in Zalivu Chesapeake}

Veliki rečni vnosi s hranili in suspendiranimi snovmi so pomembni dejavniki, ki vplivajo na delovanje ekosistemov severnega Jadrana (SJ) in Zaliva Chesapeake (CB). Oba ekosistema z različnimi geomorfološkimi lastnostmi, ki se odražajo v večji površini in globini SJ ter plitvejšem in razpotegnjenem $\mathrm{CB}$, sta podvržena podobnim letnim vnosom z rečnimi pritoki in padavinami. Pad, glavni rečni vnos v SJ, se izliva kot dvodimenzionalni linijski izvor v severozahodnem delu, v CB pa je glavni pritok Susquehanna lociran na skrajnem severu zaliva. Letni režim rečnih pritokov v CB je unimodalen s pomladnim vrhom, medtem ko je v SJ bimodalen s pomladnim in jesenskim vrhom. V obeh ekosistemih imajo vnosi velik presežek $\mathrm{N}$ glede na $\mathrm{P}$. Rečna suspendirana snov se v SJ akumulira s hitrostjo 2-6 $\mathrm{cm}$ letno ob zahodni obali, predvsem ob izlivu Pada. Hitrost akumulacije je precej nižja (0,4-1 mm letno) v vzhodnem delu SJ in Tržaškem zalivu. Pas najbolj aktivne sedimentacije ob ustju Pada vsebuje večjo frakcijo pelita (gline in melj, <63 $\mu \mathrm{m}$ ). Drobni pesek se deponira v obalnem pasu, temu pa sledi na odprtem morju področje reliktnega

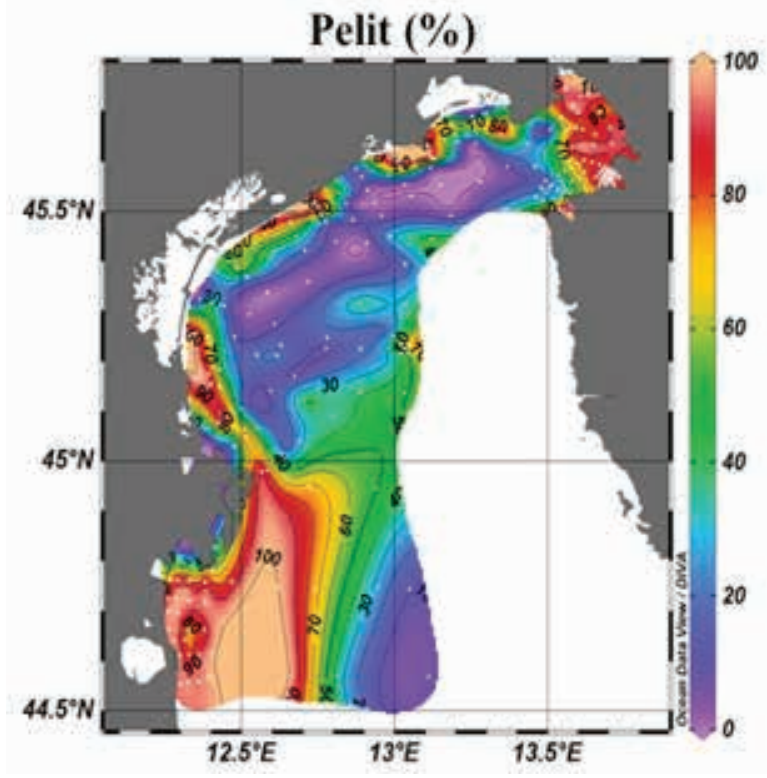

peska. Danes je v večini globljega SJ akumulacija mala ali pa je sploh ni in holocenski obalni pesek predstavlja večino recentnega sedimenta. V vzhodnem delu SJ je recentna sedimentacija delcev kopenskega izvora in avtohtonega skeletnega materiala prisotna le vzdolž zahodne istrske obale. Pozitivna korelacija med pelitom in vsebnostjo $\mathrm{C}_{\text {org. }}$. v zahodnem delu SJ odraža vpliv rečnega vnosa organske snovi in avtohtone fitoplanktonske produkcije na akumulacijo $\mathrm{C}_{\text {org. }} \mathrm{v}$ sedimentu (slika 2). Sedimentacija v CB, na katero vpliva velikost in vrsta delcev, znaša $1,3 \mathrm{~cm}$ letno, toda veliki dotoki rek, povezani s tropskimi nevihtami povzročajo večjo sedimentacijo $(4 \mathrm{~cm}$ letno) v par tednih. Peščena komponenta se praviloma akumulira $\mathrm{v}$ plitvem oligohalinem delu zaliva. Sediment globljega oligo- in mezohalinega dela zaliva je pretežno sestavljen iz pelita. Plitvi prag ob glavnem kanalu v zalivu vsebuje precej več peska, kar kaže, da je akumulirani pelit v globljem predelu manj podvržen resuspenziji. V zgornjem delu CB sedimentira pretežno rečni $\mathrm{C}_{\text {org. }}$, $\mathrm{v}$ osrednjem zaliva pa $\mathrm{C}_{\text {org. }}$. fitoplanktonskega izvora. Njuna vsebnost se nato zmanjšuje proti odprtemu delu zaliva.

V SJ se v odsotnosti vetrov vzpostavlja ciklonalno tokovanje, kot posledica vzgona in vrtenja Zemlje, kar pospešuje advekcijski tok vod Pada proti jugu (zahodnojadranski mejni tok WAC). Vetrovi spremenijo opisani vzorec. Vetrovi, ki pospešujejo tonjenje vode v zahodnem delu SJ (zimska burja) lokalizirajo izliv reke v zahodni del in pospešijo tok (WAC) v smeri juga. Nasprotno, vetrovi, ki prispevajo $\mathrm{k}$ dviganju vode (poletni jugo) potiskajo padske vode nižje slanosti proti severu in vzhodu, kar vpliva na večji zadrževalni čas hranil v SJ in s tem evtrofikacijo. Izjemoma lahko taka situacija tudi spremeni smer WAC. Klimatske spremembe bodo povečale jakost juga in s tem podvrženost SJ evtrofikaciji. Tokovanje v CB je ob odsotnosti vetrov posledica vzgona $\mathrm{v}$ delno razslojenem

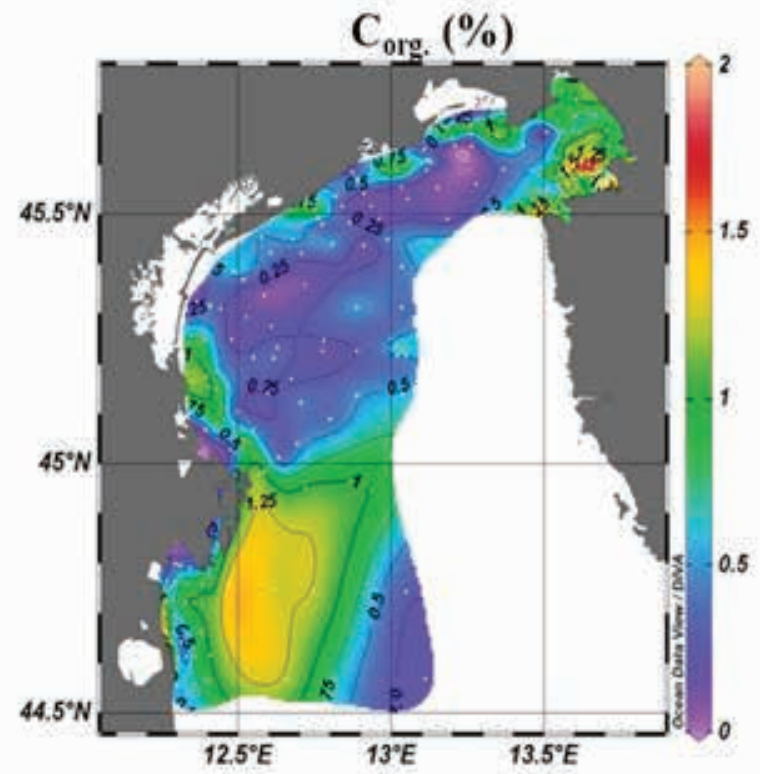

Slika 2: Porazdelitev zrnavosti (pelit $<63 \mu \mathrm{m}$ ) in vsebnosti $C_{\text {org. }}$ v površinskih sedimentih severnega Jadrana ${ }^{3}$ 
estuariju $\mathrm{s}$ tokom površinske vode $\mathrm{v}$ smeri proti morju in pridnenem toku v nasprotni smeri, proti kopnemu. Tropske nevihte (tornadi) spremenijo to gibanje s potiskanjem slane vode iz kontinentalne police $\mathrm{v}$ zaliv in posledično višanje morske gladine. Ko tropske nevihte preidejo na kopno, lokalne nevihte $\mathrm{v}$ zalivu uravnavajo slanost in gibanje vodnih mas (vzvodno ali nizvodno v odvisnosti od nevihte) $\mathrm{z}$ vertikalnim mešanjem in longitudinalnim transportom vodne mase. $\mathrm{V}$ obeh primerih povečanje padavin $\mathrm{V}$ porečju zaliva lahko vodi do večjega vnosa hranil antropogenega izvora s kopnega in evtrofikacije. Predvideno naraščanje tropskih neviht bo tako ogrozilo okoljevarstvene ukrepe in vplivalo na povečanje evtrofikacije $\mathrm{v} C B$.

Tako v SJ kot v CB največji delež primarne produkcije prispeva fitoplankton. V obeh ekosistemih fitoplankton kaže izrazito sezonsko spremenljivost biomase in produktivnosti, velika so tudi medletna nihanja. Med hranili, ki omejujejo rast, je v SJ praviloma najpomembnejši P, medtem ko v CB poleg $\mathrm{P} v$ poletnem času rast omejuje tudi $\mathrm{N}$. Kljub primerljivemu vnosu hranil v SJ in CB sta v slednjem biomasa in produkcija bistveno višja. Koncentracije klorofila $a$ so $\mathrm{v}$ SJ praviloma nižje od $5 \mathrm{mg} \mathrm{m}^{-3} \mathrm{v}$ primerjavi z razponom $5-15 \mathrm{mg} \mathrm{m}^{-3} \mathrm{v} \mathrm{CB}$. Podobno je tudi letna primarna produkcija v CB $\left(350-660 \mathrm{~g} \mathrm{C} \mathrm{m}^{-2}\right)$ skoraj štirikrat višja kot v SJ $\left(80-150 \mathrm{~g} \mathrm{C} \mathrm{m}^{-2}\right)$. Zato $\mathrm{CB}$ opredeljujemo kot evtrofen do hipertrofen ekosistem, medtem ko je SJ klasificiran kot oligotrofen do evtrofen. Primerjava rečnih vnosov $\mathrm{z}$ volumnom obeh morskih ekosistemov kaže, da ima SJ mnogo večji morski volumen. Poleg tega je za razmere $v$ SJ pomemben tudi dotok oligotrofnih južnojadranskih vod ob vzhodni obali.

Vrstna pestrost zooplanktona je v SJ višja kot v CB, kjer prevladuje nekaj zelo številnih vrst. $\mathrm{V}$ obeh ekosistemih diverziteta raste $\mathrm{z}$ naraščanjem slanosti. $\mathrm{V} S \mathrm{SJ}$ in $\mathrm{CB}$ so najpomembnejša skupina zooplanktona ceponožni raki (Copepoda). V CB njihova številčnost dolgoročno upada, nižanje pa je povezano $\mathrm{z}$ večanjem plenilskega pritiska želatinoznega planktona, predvsem rebrač. Dodaten pritisk za kopepode predstavlja hipoksija, ki v CB zavzema

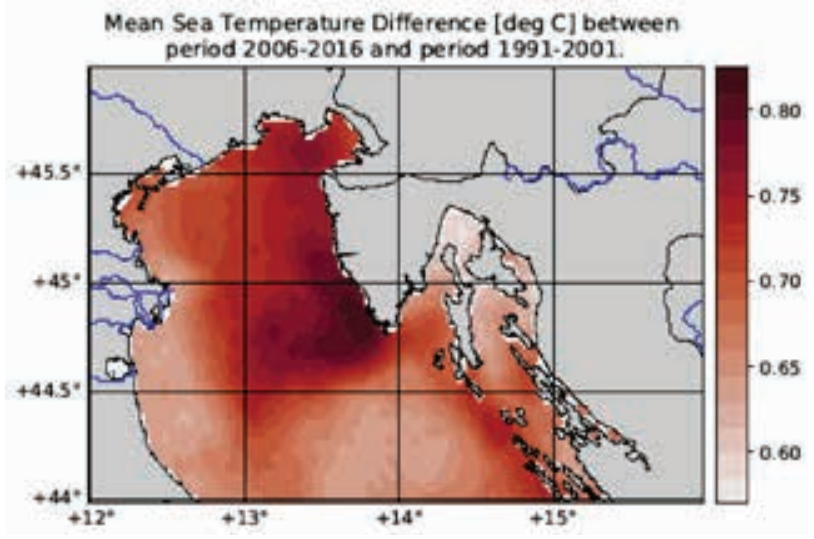

Slika 3: Razlika v satelitsko izmerjeni povprečni površinski temperaturi morja med obdobjema 2006-2016 in 1991-2001 ${ }^{4}$ velike prostorske razsežnosti in se tudi časovno podaljšuje. V SJ se v povezavi z višanjem temperature morja (slika 3 ) zmanjšuje število hladnoljubnih vrst.

$\mathrm{V}$ obeh ekosistemih $\mathrm{v}$ zadnjih desetletjih narašča številčnost želatinoznega planktona, v CB rebrač, v SJ pa klobučnjakov in od leta 2016 dalje tudi invazivne tujerodne rebrače Mnemiopsis leidyi. Te spremembe $\mathrm{v}$ sestavi planktona vplivajo tudi na številčnost in prehranjenost pelaških rib, saj povečano število želatinoznih plenilcev znižuje količino hrane za ribe.

Pikofitoplankton, heterotrofne bakterije in arheje, nanoflagelati in mikrozooplankton sestavljajo mikrobni prehranjevalni splet, ki ima prevladujoč vpliv na kroženje hranil $\mathrm{v}$ morju. V letnem poteku pikofitoplanktona je $\mathrm{v}$ obeh ekosistemih viden poletni vrh in zimski dol, toda razpon številčnosti je večji v CB $\left(10^{2}-10^{6}\right.$ celic/ml $) \mathrm{v}$ primerjavi s SJ $\left(10^{3}-10^{5}\right.$ celic/ml). Na hitrost heterotrofne bakterijske aktivnosti v obeh ekosistemih jeseni, pozimi in na pomlad vpliva predvsem temperatura, poleti pa, ko bakteriofagi omejujejo bakterijsko številčnost, prisotnost povišane koncentracije raztopljene makromolekularne (koloidne) organske snovi. Številčnost heterotrofnih bakterij in virusov sledi številčnosti pikofitoplanktona. Čeprav je razpon bakterijske produkcije $\mathrm{v}$ obeh ekosistemih približno enak $\left(0,2-280 \mathrm{mg} \mathrm{C} \mathrm{m}^{-3}\right.$ leto $\left.^{-1}\right)$, je bakterijska številčnost v CB za red velikosti večja. Opisano kaže, da je pretvorbena hitrost bakterioplanktona večja $\mathrm{v}$ SJ; razlika odseva tudi visoko razmerje virusi/bakterije v SJ v primerjavi z CB.

$\mathrm{V}$ sklopitvi pelagiala in bentosa, $\mathrm{z}$ vidika kroženja organskega $\mathrm{C}$ ter $\mathrm{N}, \mathrm{P}$ (tabela 1 ) in $\mathrm{Si}$, je razvidno, da zelo mali del suspendirane organske snovi (avtohtone kot rezultat neto primarne produkcije in alohtone $\mathrm{z}$ rečnimi pritoki) sedimentira v SJ (19\%) v primerjavi z CB (83\%). To kaže, da se v SJ večina organske snovi, nastale v primarni produkciji, razgradi v vodnem stolpu in izvozi proti jugu. Opisano je v skladu $\mathrm{z}$ večjo pretvorbeno hitrostjo bakterioplanktona in manjšo bentoško respiracijo v SJ, čeprav je bentoška respiracija sedimentirane organske snovi, ki vključuje tudi oksidacijo reduciranih kemijskih zvrsti $\mathrm{Mn}^{2+}, \mathrm{Fe}^{2+}, \mathrm{S}^{2-}$ nastalih $\mathrm{z}$ anaerobno razgradnjo organske snovi, v obeh ekosistemih približno enaka (90\%). Mala produkcija (10 \%) raztopljenega anorganskega $\mathrm{C} \mathrm{z}$ raztapljanjem karbonatov $\mathrm{v}$ sedimentih SJ poteka $\mathrm{v}$ poletnem obdobju. Tudi sproščanje regeneriranega $\mathrm{N}$ s sedimenta $\mathrm{v}$ vodni stolp je v obeh ekosistemih približno enako. Denitrifikacija je nekoliko večja $\mathrm{v}$ sedimentih $\mathrm{CB}$, kjer tudi večji delež N (45\%) ostaja trajno deponiran (»pokopan«) v sedimentu v primerjavi s SJ (23\%). Sproščena hranila se v SJ uporabljajo predvsem v bentoški primarni produkciji mikroalg, ki obsega približno 25 \% celotne (bentoške in pelaške) produkcije. Denitrifikacija in trajno deponirani $\mathrm{P}$ $\mathrm{v}$ sedimentu skupaj $\mathrm{z}$ rečnimi pritoki, osiromašenimi s $\mathrm{P}$ razložijo, zakaj je $\mathrm{P}$ omejujoči dejavnik primarne produkcije v SJ.

Ključni bentoški habitati v morskih ekosistemih SJ 
Tabela 1: Primerjava med masnima bilancama $\mathrm{C}_{\text {org. }}, \mathrm{N}$ in $\mathrm{P}$ severnem Jadranu (SJ) in zalivu Chesapeake $(\mathrm{CB})\left(\mathrm{mol} \mathrm{m}^{-2}\right.$ leto $\left.^{-1}\right),{ }^{*}$ depozicija korigirana glede na resuspenzijo, ${ }^{* *}$ področja $\mathrm{z}$ aktivno sedimentacijo $^{3}$

\begin{tabular}{llcccccc}
\hline Habitat & Proces & \multicolumn{2}{c}{$\mathbf{C}_{\text {org }}$} & \multicolumn{2}{c}{$\mathbf{N}$} & \multicolumn{2}{c}{ P } \\
& & SJ & CB & SJ & CB & SJ & CB \\
\hline Pelagial & Rečni vnos & 6,5 & 4,1 & 0,7 & 0,9 & 0,03 & 0,02 \\
& Rečni vnos DOC & 3,2 & 0,8 & & & & \\
& NPP & 8,4 & 45 & & & & \\
& Asimilacija & & & 1,27 & 8,27 & 0,08 & 0,49 \\
& Respiracija planktona & 11,5 & 38 & & & & \\
\hline Bentos & Depozicija* & 3,4 & 18 & 0,40 & 2,3 & 0,02 & 0,11 \\
& Produkcija MPB & 2,3 & 0,8 & & & & \\
& Asimilacija & & & 0,34 & 0,12 & 0,02 & 0,01 \\
& Recikliranje & & & 0,18 & 0,33 & 0,01 & 0,05 \\
& Denitrifikacija & & & 0,30 & 0,53 & & \\
& Respiracija & 4,9 & 17 & & & & \\
& Trajna depozicija & 1,1 & 3,4 & 0,09 & 1,02 & 0,01 & 0,10 \\
& Razlike & $-0,4$ & - & 0,3 & - & 0,01 & - \\
\hline
\end{tabular}

in $\mathrm{CB}$ vključujejo grebene ostrig (CB) in koralne grebene (SJ), podvodno vegetacijo (alge in trave), obalna mokrišča in lagune. Grebeni ostrig in koral, podvodni travniki in razrast alg (slika 4) sodijo med ekosistemske gradnike, ki zagotavljajo številčnost in pestrost $\mathrm{z}$ njimi povezanih komercialnih in nekomercialnih organizmov. Najpomembnejši vzroki za degradacijo bentoških habitatov v obeh morskih sistemih so antropogeno preoblikovanje obalne črte in širjenje urbane infrastrukture, vnosi hranil in tujerodnih vrst, povečan pomorski promet, dvigovanje sedimentov, prelov in podnebne spremembe. Verjetno je, da se bo večina teh pritiskov ohranila tudi v bodoče in tako ogrožala za ljudi pomembne ekosistemske usluge, kot so zaščita obale in kontrola erozije, ribištvo, biotska pestrost, ohranjanje kakovosti morja.

Oba ekosistema podpirata ekonomsko pomembno ribiško dejavnost in pri nekaterih vrstah se kažejo znaki prelova. V SJ je število ribjih vrst v celoti višje in tudi ulov

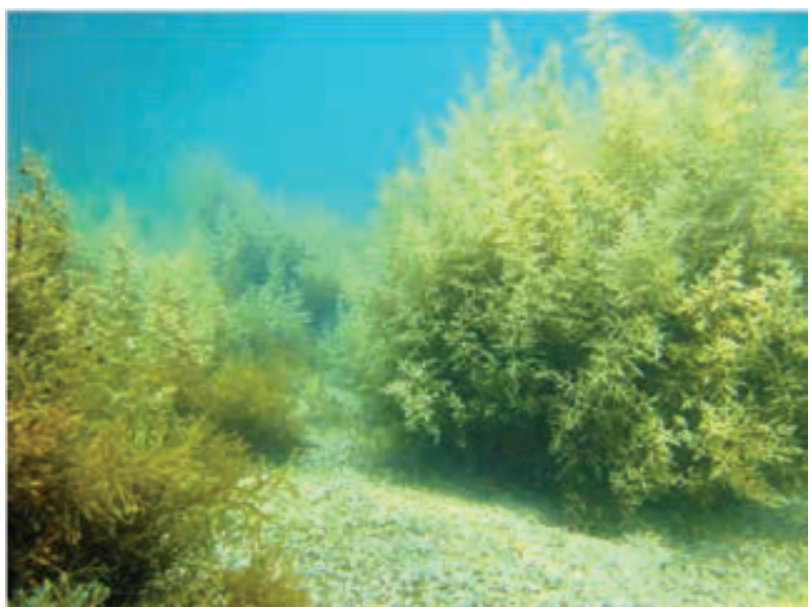

Slika 4: Podvodni "gozdički« cistozir so pomembni ekosistemski gradniki (Foto: B. Mavrič) vključuje večje število vrst kot $\mathrm{v} C \mathrm{CB}$. V obeh ekosistemih je pomemben ulov male pelaške ribe: v SJ Engraulis encrasicolus, Sardina pilchardus, Sprattus sprattus, v CB pa Brevoortia tyrranus. Med demerzalnimi ribami so v SJ najpomembnejše Merluccius merluccius, Mullus barbatus, Solea solea in Sparus aurata, v CB pa Micropogonias undulates, Leiostomus xanthurus in Paralichthys dentatus. Med nevretenčarji v SJ lovijo več vrst rakov in mehkužcev, medtem ko je v CB lov osredotočen na posamezno vrsto rakov (Callinectes sapidus) in školjk (Crassostrea virginica). Medtem ko je skupni ulov v SJ zrasel od 140000 t na leto v obdobju $1992-2002$ na 180000 ton leta 2016, je v istem obdobju v CB upadel od 350000 na okoli 200000 t na leto. $\mathrm{Na}$ enoto fitoplanktonske produkcije je ulov v SJ približno 1,5 krat višji kot v CB.

Antropogeni vplivi na ekologijo in ekosistemske storitve so znatni v obeh sistemih. Kot indikatorje stanja ekosistemov uporabljamo prostorsko razsežnost ključnih habitatov (podvodni travniki, školjčni in koralni grebeni, mokrišča), fitoplanktonktonsko produkcijo, številčnost zooplanktona, številčnost morskih virov - rib, školjk, rakov, številčnost filtratorjev, prostorsko razsežnost hipoksij in anoksij, pogostost škodljivih cvetenj fitoplanktona, številčnost želatinoznega planktona, zakisanost, površinsko temperaturo, nivo gladine morja. Med pritiski imajo najširši negativen učinek na stanje ekosistemov in ekosistemskih storitev vnosi hranil in podnebne spremembe (tabela 2).

Evtrofikacija, katere posledice so izgube habitatov, zmanjšanja evfotske globine $\mathrm{v}$ vodnem stolpu, daljši časovni in večji prostorski obseg hipoksij in anoksij ter pojavljanje škodljivih cvetenj mikroalg, je v SJ in CB najpomembnejši dejavnik, ki vpliva na izkoriščanje obeh ekosistemov. Rečni vnosi N (CB) in P (SJ) antropogenega izvora so najpomembnejši vzroki evtrofikacije in $\mathrm{z}$ njo povezanih destruktivnih procesov v ekosistemih. $\mathrm{V}$ obeh ekosistemih je dolgoročno dokumentirana »kulturna« evtrofikacija kot 
Tabela 2: Vpliv vrednosti indikatorjev stanja ekosistemov na izboljšanje $(+)$ oz. poslabšanje $(\downarrow)$ ekosistemskih storitev. Indikatorji stanja: $\mathrm{Hab}=$ stanje habitatov; NPP = neto primarna produkcija; Zoo = številčnost zooplanktona; $\mathrm{MV}$ = živi morski viri; $\mathrm{F}$ = številčnost filtratorjev; Hyp = časovna in prostorska razsežnost hipoksij/anoksij; Tox = pogostost pojavov škodljivih cvetenj fitoplanktona; Žel = številčnost želatinoznih organizmov (meduze, rebrače); Kis = kisanje morja; $\mathrm{T}^{0}=$ površinska temperatura; $\mathrm{GM}=$ gladina morja Ekosistemske storitve: (1) ribolov (ribe, mehkužci, raki); (2) vzdrževanje kakovosti morja (kroženje hranil, prehranjevanje filtratorjev, stabilizacija morskega dna); (3) odpornost obale (stabilizacija obale, manjšanje erozije, zadrževanje poplav); (4) podpora biotski pestrosti (biološko strukturirani habitati, različne vrste, reprodukcija, zaščita pred predatorji); (5) sekvestracija ogljika (kontrola ogljika $\mathrm{v}$ atmosferi in vpliv na podnebne razmere); (6) estetska vrednost (turizem, rekreacija, kultura); prirejeno po Malone in sod. ${ }^{5}$

\begin{tabular}{lcccccccccccc}
\hline $\begin{array}{l}\text { Ekosistemske } \\
\text { storitve }\end{array}$ & Hab & NPP & Zoo & MV & F & Hyp & Tox & Žel & Kis & T $^{0}$ & GM \\
\hline 1.Ribolov & + & + & + & + & + & $\downarrow$ & $\downarrow$ & $\downarrow$ & $\downarrow$ & $\downarrow$ & \\
2.Kakovost morja & + & & & & + & $\downarrow$ & $\downarrow$ & & $\downarrow$ & $\downarrow$ & \\
3. Odpornost obale & + & & & & & $\downarrow$ & & & & & $\downarrow$ \\
4.Pestrost organiz. & + & + & + & + & + & $\downarrow$ & $\downarrow$ & $\downarrow$ & $\downarrow$ & $\downarrow$ & \\
5.Sekvestracija C & + & + & & & & $\downarrow$ & & & & $\downarrow$ & \\
6.Estetska vrednost & + & & & & & & $\downarrow$ & $\downarrow$ & & & & \\
\hline
\end{tabular}

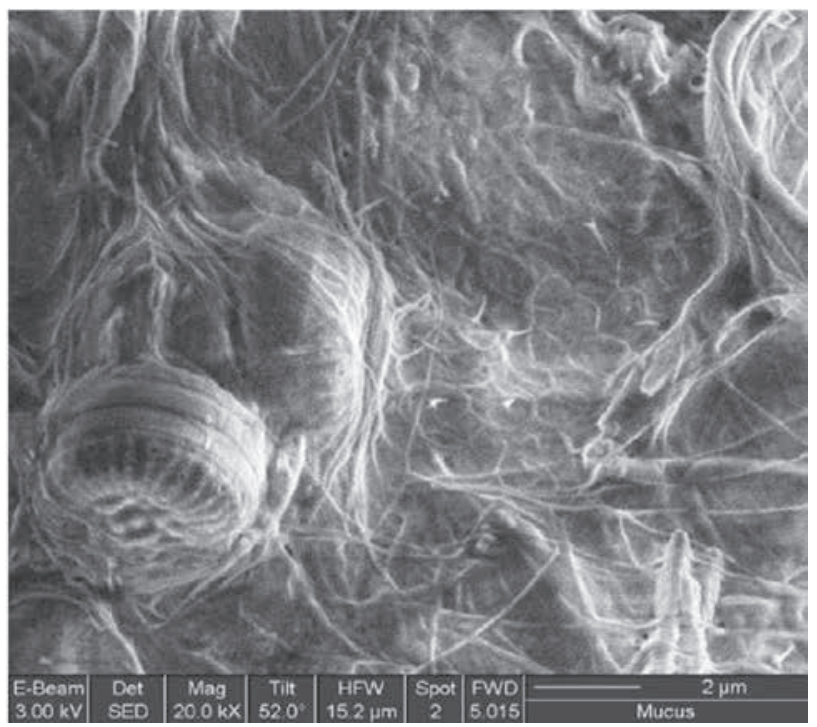

Slika 5: Posnetek makroagregatov iz Tržaškega zaliva $\mathrm{z}$ vkleščeno diatomejo z elekronsko vrstično mikroskopijo ${ }^{6}$

posledica vnosa hranil, $\mathrm{z}$ vidnim pospeškom po 2 . svetovni vojni, vendar je bolj evtrofen CB. SJ je evtrofen le ob izlivih rek ob severni in zahodni obali. V SJ so bolj prisotni toksični fitoplanktonski rodovi, med katerini so Lingulodinium, Prorocentrum, Dinophysis in Alexandrium prisotni tudi v CB. Le v SJ smo beležili edinstven sezonski pojav sluzi (lipidnih in heteropolisharidnih makroagregatov) kot posledica akumulacije koloidne organske snovi pozno pomladi (slika 5), Sedimentacija sluzi je povzročila lokalno pomanjkanje kisika pri dnu, hipoksijo in celo anoksijo s posledičnim pomorom bentoških organizmov.

Zaradi zmanjšanja vnosa antropogenih hranil v zadnjih desetletjih (po 1985), P v SJ in N v CB, se je evtrofikacija obeh ekosistemov zmanjšala, vendar $\mathrm{v}$ celoti ne dosega končnega cilja kvalitete vod, zapisanega v smernicah evropskih direktiv (EU Water Framework Directive, Marine Strategy Directive) in programa za Zaliv Chesapeake (Chesapeake Bay Program). ${ }^{78}$ Upravljalski posegi so vplivali na znižanje koncentracij P v SJ in N v CB, a ostaja problem povečanja koncentracije celotnega $\mathrm{N} v$ vodah SJ in celotnega $\mathrm{P} \vee \mathrm{CB}$. Z nadaljevanjem asanacijskih in restavracijskih posegov je pomembno dokumentirati izboljšanje stanja in razumenti, kako na spremembe ekosistemov vplivajo drugi antropogeni pritiski vključno s klimatskimi spremembami, ribištvom in izkoriščanjem obalnega področja. Padec $\mathrm{pH}$, »kisanje« morja, je posebno v estuarijih lahko posledica evtrofikacije. SJ je danes ponor $\mathrm{CO}_{2} \mathrm{z}$ letnim tokom -1.2 to $-3 \mathrm{~mol} \mathrm{C} \mathrm{m}{ }^{-2}$, istega reda velikosti kot v severozahodnem Sredozemlju. Nanj vplivajo predvsem temperatura in vetrovi, manj poraba fitoplanktona. Ocenjeni 25-letni (1983-2008) padec $\mathrm{pH}$ v vodah SJ je 0,003, podobno kot v širšem Sredozemlju. Izračunani Revellov faktor ("pufranost«) za SJ je približno 10, kar kaže, da je puferska kapaciteta visoka in da SJ ni podvržen »kisanju«. Celotna alkalnost je visoka $\left(2,6-2,7 \mathrm{mmol} \mathrm{l}^{-1}\right)$, na zgornji meji v Sredozemlju, takoj za Egejskim morjem, predvsem zaradi vnosa karbonata $\mathrm{Z}$ alpskimi in kraškimi rekami. Približno 60 \% vnosa alkalnosti prispeva Pad ( 3 mmol $\left.\mathrm{I}^{-1}\right)$ in ta pada $\mathrm{z}$ naraščajočo slanostjo. Vode SJ so prenasičene glede na kalcit $\left(\Omega_{\mathrm{Ca}}\right)$ in aragonit $\left(\Omega_{\mathrm{Ar}}\right)$ v celem letu, vendar je v obdobju gostotne stratifikacije vodnega stolpa nasičenost precej nižja $\mathrm{v}$ sloju pri dnu zaradi remineralizacijskih procesov v sedimentu. $\mathrm{CB}$ je ponor $\mathrm{CO}_{2}$ in šibek izvor alkalnosti z nizko pufersko kapaciteto. Vzrok je mešanje rečne in morske vode ter produkcija $\mathrm{CO}_{2} \mathrm{z}$ anaerobnimi redoks reakcijami (dihanja), ki danes presega vnos atmosferskga $\mathrm{CO}_{2}$. Alkalnost narašča $\mathrm{v}$ smeri morja (s slanostjo) in z globino. 15-letni padec $\mathrm{pH}$ v odprtem delu zaliva znaša 0,11 , do naraščanja $\mathrm{v}$ osrednjem $(0,12)$ in zgornjem $(0,16)$ delu zaliva pa prihaja zaradi dolgoroč- 
nega porasta $\mathrm{pH}$ reke Susquehanna. V pridnenih vodah je trend podoben, kar ne kaže na »kisanje« zaradi razgradnje organske snovi.

Povečanje temperature površinske plasti morja in $s$ tem povečanje vertikalne temperaturne in gostotne stratifikacije zaradi podnebnih sprememb in zvečanje jakosti vetrov, spremembe padavin (povečanje v porečju CB in zmanjšanje v SJ) in zvišanje morske gladine (približno enako $\mathrm{v}$ obeh ekosistemih) spreminjajo sistem tokovanja in mešanja vodnih mas ter valovanja. Vse te spremembe vplivajo na razmere $\mathrm{v}$ obeh ekosistemih in njihovo izkoriščanje. V SJ in $\mathrm{v}$ porečju bi zmanjšana količina letnih padavin pospešila oligotrofikacijo ${ }^{9}, \mathrm{v} C B$ pa $\mathrm{v}$ povezavi $\mathrm{s}$ povišano temperaturo povečan prostorski in časovni obseg hipoksij v pridnenem sloju kljub zmanjšanemu vnosu hranil. ${ }^{10}$ Zvišanje temperature $\mathrm{v}$ obeh ekosistemih bo pospešilo rast toploljubnih (termofilnih) vrst. Morska trava Zostera marina je tako prisotna na svojem južnem robu v obeh ekosistemih in toplejše poletne vode so lahko vzrok za zmanjšano številčnost oziroma pomembno regresijo vrste. Povečanje temperature oziroma ekstremni temperaturni pojavi lahko pospešijo odmiranje koralnih grebenov v SJ. Povišana temperatura bo spremenila sukcesije hladno- in toploljubnih vrst $\mathrm{z}$ daljšim poletnim obdobjem in večjo prisotnostjo vrst kot so npr. Chrysaora spp., Mnemiopsis leidyi. Zaradi povišane temperature $\mathrm{v} C B$ ni več prisoten hladnoljuben kopepod Acartia hudsonica. Povišana temperatura bo verjetno pospešila pretok snovi v mikrobnem spletu $\mathrm{v}$ primerjavi $\mathrm{z}$ metazojskim, kar ima negativne posledice za prehrano rib. Dvig gladine morja in ekstremni vremenski pojavi bodo povečali nevarnost poplav in erozije. Slana močvirja bodo poplavljena. Organizmi v CB bodo bolj podvržen »kisanju « kot v SJ, saj ima slednji zaradi manjših časovnih in prostorskih razsežnosti hipoksij ter vnosa karbonata alpskih rek, visoko pufersko kapaciteto. Kljub prenasičenosti glede na kalcit in aragonit, pa v prihodnosti lahko pričakujemo vplive »kisanja « tudi v SJ, saj karbonatni organizmi potrebujejo visok indeks nasičenja.

\section{Sinergije}

Tako CB kot tudi SJ sta v celoletnem časovnem obdobju avtotrofna sistema, $\mathrm{v}$ katerih je primarna produkcija višja kot respiracija. V CB ekosistemu se suspendirani $\mathrm{C}$ pretaka na kontinentalno polico, medtem ko fitoplanktonska produkcija $\mathrm{v}$ povezavi s tvorbo goste jadranske vode $\mathrm{v}$ severnem Jadranu pospešuje prenos ogljika v Sredozemsko morje in s tem prispeva k nižanju atmosferskega $\mathrm{CO}_{2} .{ }^{11}$ Zaradi podnebnih sprememb in višanja temperature bo predvidoma tvorba goste vode $\mathrm{v} S \mathrm{JJ}$ zmanjšana in $s$ tem se bo znižala tudi sekvestracija atmosferskega $\mathrm{CO}_{2}$.

Dvig temperature skupaj $\mathrm{z}$ ribolovnim pritiskom spreminja sestavo ribje združbe od prevlade velikih vrst, ki spolno dozorijo pozno in imajo maloštevilno potomstva, $\mathrm{v}$ združbo $\mathrm{z}$ majhnimi vrstami in zgodnjo spolno zrelo- stjo ter številnim potomstvom, katerih mesto je nižje $\mathrm{v}$ prehranjevalnem spletu. Podnebne spremembe s segrevanjem morja negativno vplivajo na hladnoljubne, borealne ribe (Sprattus sprattus, Merlangius merlangus), ki so v severnem Jadranu bolj razširjene kot v preostalem delu Sredozemskega morja. Po drugi strani je večja številčnost komercionalno pomembne kozice Penaeus kerathurus povezana s segrevanjem Jadranskega morja.

Izguba pomembnih habitatov $\mathrm{v}$ obeh sistemih je povezana $s$ pridnenim pomanjkanjem kisika (hipoksija, anoksija) in $\mathrm{z}$ antropogeno degradacijo okolja. $\mathrm{V}$ obeh sistemih se sezonska hipoksija razvije $\mathrm{v}$ poletnem in zgodnjejesenskem obdobju. V CB hipoksija zajame celotno mezohalino območje, medtem ko je v SJ tako prostorsko kot tudi časovno manj predvidljiva. Pomanjkanje kisika ob dnu pomembno vpliva na ključne habitate $\mathrm{v}$ obeh ekosistemih. Naraščajoči vnosi hranil v oba sistema so v preteklih obdobjih (1945-1985) povzročili propad ali zmanjšanje pomembnih habitatov: grebenov ostrig v CB, koralnih grebenov in travnikov ter pokrovnosti makroalg v SJ. Izgubo pomembnih habitatov so še poslabšale gradnje številnih obalnih infastruktur, dvig temperature in invazije tujerodnih organizmov. Pozitiven znak je, da se v ključnih habitatih po zmanjšanju antropogenih pritiskov razmere izboljšujejo.

\section{Monitoring in modeliranje}

Glede na opisane antropogene pritiske je za trajnostni razvoj nujen pristop ekosistemskega upravljanja (EKOU), ki upošteva socialno-ekonomski razvoj in dinamiko ekosistemov ${ }^{5}$. Ekonomske dejavnosti, ki potekajo v mreži socialnih interakcij, so tako omejene z razpoložljivostjo ekosistemskih storitev. EKOU potencialno zagotavlja stroškovno učinkovite rešitve za doseganje pogosto konfliktnih ciljev socialno-ekonomskega razvoja in trajnostne rabe okolja. Temelj trajnostnega socialno-ekonomskega razvoja in rabe ekosistemskih storitev je dobro stanje ekosistemov. Zato je za učinkovit EKOU nujno spremljanje (monitoring) ekosistemov s primernimi časovnimi presledki in $\mathrm{v}$ zadostni prostorski razsežnosti ter redna analiza in poročanje o stanju. ${ }^{5}$

Napredek v znanstvenem razumevanju obalnih ekosistemov in predvidljivost sprememb stanja sta ključna tudi za ugotavljanje sposobnosti ekosistemov $\mathrm{SJ}$ in $\mathrm{CB}$ za trajnostne ekosistemske storitve. Pri tem sta ključna monitoring obeh sistemov in modeliranje procesov. Za EKOU je potrebna integralna ocena stanja (IEA) v kateri so vključeni državljani, predstavniki industrij, znanstveniki, upravljavci virov, politiki ${ }^{12}$, ki zagotovijo:

(1) soglasje o prioritetnih ekoloških, socialnih in ekonomskih ciljih, ki pomagajo opredeliti usmeritve politikov in upravljavcev,

(2) opredelitev antropogenih pritiskov na ekosisteme ter stanje ekosistemov na osnovi indikatorjev, oceno sta- 
nja in trendov ekosistemskih storitev glede na dogovorjene cilje (tj. doseganje ekosistemskih storitev na želenem nivoju),

(3) opredelitev naravnih in antropogenih (ekoloških, socialnih, ekonomskih) vzrokov in posledic ugotovljenih trendov stanja ekosistemov in ekosistemskih storitev,

(4) predvidevanja sprememb v stanju ekosistemov in ekosistemskih storitvah glede na opredeljene dejavnosti,

(5) rutinsko preverjanje učinkovitosti ukrepov $\mathrm{v}$ rednih časovnih presledkih in v povezavi z opredeljenimi cilji,

(6) identifikacijo ključnih pomanjkljivosti $\mathrm{v}$ znanju in razpoložljivih podatkih ter modelih, ki so nujni za izboljšanje integralne ocene stanja.

Danes je zmožnost modeliranih napovedi tokovanja in mešanja vodnih mas omejena $\mathrm{z}$ nezanesljivostjo regionalnih napovedi sprememb padavin, rečnih pritokov in vetrov. Izboljšane napovedi fizikalnih sprememb in stanja ekosistemov zahteva $\mathrm{v}$ regionalnem okviru vzdržno in zelo pogosto sinoptično merjenje in modeliranje sprememb gradientov atmosferskega tlaka, tokov toplote in $\mathrm{CO}_{2}$ med atmosfero in morjem, ekstremnih vetrov (burje, juga, tropskih neviht), okoljskih lastnosti ekosistema (temperature, slanosti, hranil, kisika, vertikalnega mešanja, prostorske porazdelitve habitatov, gostote invazivnih vrst) in gostote in porazdelitve ključnih skupin organizmov (fitoplanktona, kopepodov, želatinoznega zooplanktona, ključnih predatorjev in izbranih ribjih populacij). Uporabo podobnega pristopa načrtujemo tudi v prihodnjem primerjalnem prikazu izvora in porazdelitve onesnaževal (kovin, radionuklidov, organskih onesnaževal, plastike, termičnega onesnaževanja, hrupa) v SJ in CB.

\section{Literatura}

1. T. C. Malone, A. Malej, J. Faganeli (Ed.): Coastal Ecosystems in Transition: A Comparative Analysis of the Northern Adriatic and Chesapeake Bay, AGU Wiley, New Jersey, 2021.

2. T. C, Malone, A. Malej, L. W. Harding, N. Smodlaka, R. E.
Turner (Ed.): Ecosystems at the Land-Sea Margin: Watershed to the Coastal Sea, AGU, Washington DC, 1999.

DOI:10.1029/CE055

3. J.M. Testa, J. Faganeli, M. Giani, M. J. Brush, C. De Vittor, W. R. Boynton, S. Covelli, W. M. Kemp, N. Kovač, R. Woodland, in: T. C. Malone, A. Malej, J. Faganeli (Ed.): Coastal Ecosystems in Transition: A Comparative Analysis of the Northern Adriatic and Chesapeake Bay, AGU Wiley, New Jersey, 2021.

4. A. Malej, D. Lučić, M. Ličer, T. Kogovšek, P. Lučić, in: Ocean Sciences Meeting, San Diego, Ca., 2020, https://agu.confex.com/agu/osm20/meetingapp.cgi/Paper/ 645896.

5. T.C. Malone, P.M. DiGiacomo, E. Gonçalves, A.H. Knap, L. Talaue-McManus, S. de Mora, Mar. Policy, 2014, 43, 262-272. DOI:10.1016/j.marpol.2013.06.008

6. V. Turk, V. Flander-Putrle, A. Malej, in: ASLO 2005 Summer Meeting: A pilgrimage through global aquatic sciences, Santiago de Compostela, Spain, 2005, www.aslo.org/santiago2005.

7. M. Herrmann, S. Doney, T. Ezer, K. Gedan, P. Morefield, B. Muhling, D. Pirhalla. S. Shaw, Scientific and Technical Advisory Committee review of the Chesapeake Bay Program partnership's climate change assessment framework and programmatic integration and response efforts. STAC Publication Number 18-001, Edgewater, MD., 2018.

8. N.Voulvoulis, K.D. Arpon, T. Giakoumis, Sci. Tot. Environ., 2017, 575, 358-366. DOI:10.1007/s12237-009-9191-7

9. P. Mozetič, C. Solidoro, G. Cossarini, G. Socal, R. Precali, J. Francé, F. Bianchi, C. De Vittor, N. Smodlaka, S. Fonda Umani, Estuar. Coasts, 2010, 33, 362-375.

10. C. R. Pyke, R. G. Najjar, M. B. Adams, D. Breitburg, C. Herschner, R. Howarth, M. Kemp, M. Mulholland, M. Paolisso, D. Secor, K. Sellner, D. Wardrop, R. Wood, Climate Change and the Chesapeake Bay: State-of-the-Science Review and Recommendations. Technical Advisory Committee (STAC) Publication \#08-004, Annapolis, MD., 2008.

11. G. Cossarini, S. Querin, C. Solidoro, Ecol.Model., 2015, 118 134. DOI:10.1016/j.ecolmodel.2015.07.024

12. P. S. Levin, M. J. Fogarty, S. A. Murawski, D. Fluharty, PLoS Biol., 2009, 7(1), e1000014.

DOI:10.1371/journal.pbio.1000014

\begin{abstract}
A new book in press entitled Coastal Ecosystems in Transition: A Comparative Analysis of the Northern Adriatic and Chesapeake Bay (AGU Wiley, New Jersey) edited by T.C. Malone, A. Malej and J. Faganeli is presented. This book reports the comparison of ecosystems of the northern Adriatric and the Chesapeake Bay. It enlarges our knowledge of anthropogenic pressures on coastal ecosystems where is concentrated the majority of the population and the exploitation of natural resources. The revisited ecosystems permitted to evaluate changes, particularly local, over the last twenty years in the context of global climate changes and to evaluate the success of management efforts and reduction of anthropogenic pressures on coastal ecosystems.
\end{abstract}

Except when otherwise noted, articles in this journal are published under the terms and conditions of the Creative Commons Attribution 4.0 International License 